\title{
Pathogenicity of Beauveria bassiana Vuill in Compost Media for Oryctes rhinoceros L. Oil Palm Pest Control
}

\author{
Rina Novianti ${ }^{1}$, Hafiz Fauzana ${ }^{2 *}$, Rusli Rustam ${ }^{2}$ \\ ${ }^{1}$ Student of Master of Agricultural Science Study Program, Postgraduate University of Riau \\ ${ }^{2}$ Teaching Staff of the Department of Agrotechnology, Faculty of Agriculture, Riau University \\ *Corresponding Author: fauzana_hafiz@yahoo.co.id
}

Received December 10, 2020; revised April 05, 2021; accepted June 28, 2021

\begin{abstract}
The Oryctes rhinoceros pest is an important pest of palm oil plant. Pest problems occur because Oil Palm Empty Fruit Bunches (OPEFB) is added for soil fertility to create a breeding site for larvae O. rhinoceros. Generally, OPEFB will receive the plants more quickly when composted, and pest control is carried out in the compost. Biological control is more recommended because it is environmentally friendly, Therefore compost is added with biological control agent $O$. rhinoceros namely B. bassiana. This study is aimed to obtain the best conidia density of Beauveria bassiana in compost in controlling larvae O. rhinoceros. The research was carried out at the Plant Pest Laboratory and Experimental Garden, Faculty of Agriculture, Riau of University. The study was carried out from February to November 2020. The experiment on the conidia density of $B$. bassiana fungi in compost media against larvae $O$. rhinoceros, using a Completely Randomized Design (CRD), with 6 treatments 4 replications obtained 24 experimental units, while the treatments were 0 g. $1^{-1}, 15$ g. $l^{-1}, 30$ g. $1^{-1}, 45$ g. $l^{-1}, 60$ g. $l^{-1}$ and 75 g..$^{-1}$. The results of the research revealed that OPEFB compost + sawdust containing the fungus $B$. bassiana $75 \mathrm{~g}^{-1} \mathrm{l}^{-1}\left(83,2 \times 10^{8} \mathrm{kon} / \mathrm{ml}\right)$ had the best ability to control larvae $O$. rhinoceros with a total larvae mortality of $87 \%$ which caused early death of 54 hours after application, $\mathrm{LT}_{50}$ of 213 hours after application, and $\mathrm{LC}_{50}$ of $3,3 \%$ or the equivalent of $33 \mathrm{~g} . \mathrm{l}^{-1}$ at 14 days after application.
\end{abstract}

Keywords: Oil palm, Oryctes rhinoceros, Beauveria bassiana, biological control, compost

ABSTRAK

Patogenitas Beauveria bassiana Vuill pada Media Kompos untuk Pengendalian Hama Kelapa Sawit Oryctes rhinoceros $\mathbf{L}$.

Oryctes rhinoceros merupakan hama penting pada kelapa sawit. Permasalahan hama terjadi karena pemberian tandan kosong kelapa sawit (TKKS) untuk kesuburan tanah menjadi tempat berkembang biak larva $O$. rhinoceros. Umumnya TKKS lebih cepat haranya tersedia untuk tanaman bila dikomposkan dan pengendalian hama dapat dilakukan pada kompos tersebut. Oryctes rhinoceros pengendaliannya lebih dianjurkan menggunakan agen hayati karena lebih ramah lingkungan, oleh karena itu pada kompos agens hayati diaplikasikan yaitu jamur Beauveria bassiana. Penelitian bertujuan untuk mendapatkan kerapatan konidia terbaik Beauveria bassiana pada kompos dalam mengendalikan larva O. rhinoceros. Penelitian dilaksanakan di Laboratorium Hama Tumbuhan dan Kebun Percobaan Fakultas Pertanian Universitas Riau. Penelitian dilaksanakan pada bulan Februari sampai November 2020. Percobaan uji kerapatan konidia cendawan B. bassiana pada media kompos terhadap larva $O$. rhinoceros, menggunakan Rancangan Acak Lengkap (RAL), dengan 6 perlakuan 4 ulangan didapatkan 24 unit percobaan, adapun perlakuannya yaitu 0 g. $l^{-1}, 15$ g. $l^{-1}, 30$ g. $l^{-1}, 45$ g. $l^{-1}, 60$ g..$^{-1}$ dan 75 g. $l^{-1}$. Hasil penelitian adalah kompos TKKS+ serbuk gergaji yang mengandung cendawan B. bassiana $75 \mathrm{~g} .1^{-1}\left(83,2 \times 10^{8} \mathrm{kon} / \mathrm{ml}\right)$ memiliki kemampuan terbaik dalam mengendalikan larva $O$. rhinoceros dengan mortalitas total larva sebesar $87 \%$ yang menyebabkan awal kematian 54 jam setelah aplikasi, $\mathrm{LT}_{50}$ yaitu 213 jam setelah aplikasi dan $\mathrm{LC}_{50}$ sebesar $3,3 \%$ atau setara 33 g..$^{-1}$ pada 14 hari setelah aplikasi.

Kata Kunci: Kelapa sawit, Oryctes rhinoceros, Beauveria bassiana, pengendalian hayati, kompos.

\section{PENDAHULUAN}

Kelapa sawit adalah tanaman perkebunan penting penghasil minyak makanan, minyak industri, maupun biodiesel (Kiswanto et al., 2008). Perkebunan kelapa sawit di Riau mengalami peningkatan. Luas areal perkebunan kelapa sawit di Riau pada tahun 2014 mencapai 2.411.819 ha dengan produksi 7.761.293 ton sedangkan pada tahun 2015 luas lahan meningkat menjadi 2.424 .545 ha dengan produksi sebesar 7.841.947 ton (BPS, 2017).

Pengolahan kelapa sawit menghasilkan limbah padat berupa Tandan Kosong Kelapa Sawit (TKKS).
Limbah padat yang dihasilkan berbanding lurus dengan jumlah tandan buah segar yang dihasilkan (Rahmadi et al, 2014). Limbah TKKS diletakan di tanaman untuk meningkat unsur hara tanah sebagai fertilizer. TKKS perombakannya berlangsung lama, oleh karena itu lebih baik TKKS dijadikan sebagai kompos. Kompos TKKS unsur haranya segera tersedia untuk tanaman. Kompos TKKS dapat menambah unsur hara, meningkatkan kandungan bahan organik tanah, sehingga struktur tanah semakin bagus dan kemampuan tanah menahan air bertambah baik (Purnamayani, 2013). Masalah yang 
terjadi saat ini, pemberian TKKS maupun yang sudah dikomposkan menjadi tempat breeding site Oryctes rhinoceros. Menurut Bedford (2013) media kompos dijadikan sebagai sarang aktif dan juga tempat berkembang biak (telur hingga pupa) hama $O$. rhinoceros.

Oryctes rhinoceros merupakan hama penting pada kelapa sawit. Serangan hama $O$. rhinoceros di Provinsi Riau seluas 12.384,85 ha (Dinas Perkebunan Provinsi Riau, 2014). Daud (2007) menyatakan bahwa serangan hama ini dapat menyebabkan kematian tanaman apabila menyerang titik tumbuh kelapa sawit. Kepadatan populasi $O$. rhinoceros dipengaruhi oleh faktor cuaca (suhu, kelembaban udara relatif, curah hujan), faktor biotik (musuh alami) dan ketersediaan pakan (bahan organik dalam tanah). Pelapukan tandan kosong kelapa sawit yang sempurna dan kelembaban mikro pada TKKS yang tinggi merupakan habitat yang cocok untuk larva $O$. rhinoceros. Larva ditemukan pada kedalaman tandan kosong dari 10-35 cm (Pujiastuti et al., 2010).

Umumnya pengendalian imago $O$. rhinoceros yang dilakukan petani dengan menggunakan insektisida sintetik, namun banyak pengaruh buruk yang ditimbulkan bagi manusia dan lingkungan. Oleh karena itu, perlu diupayakan pengendalian yang ramah lingkungan dengan menggunakan agensia hayati. Kelebihan pemanfaatan agen hayati yaitu mempunyai kapasitas reproduksi yang tinggi, siklus hidupnya pendek, dapat membentuk spora yang tahan lama di alam walaupun dalam kondisi yang tidak menguntungkan, relatif aman, selektif, relatif mudah diproduksi, dan sangat kecil kemungkinan menyebabkan resistensi hama (Prayogo et al., 2005).

Beauveria bassiana merupakan agensia hayati dari cendawan yang dapat dimanfaatkan sebagai bahan pengendalian untuk banyak serangga hama. Selain itu cendawan entomopatogen $B$. bassiana ini memiliki keanekaragaman infeksi yang luas mulai dari telur, larva, pupa sampai imago. B. bassiana mempenetrasi tubuh inang dengan bantuan tekanan mekanik dan bantuan toksin beauvericin yang dikeluarkan oleh cendawan. Serangga dapat terinfeksi konidia melalui kutikula, atau melalui celah di antara segmen-segmen tubuhnya, kemudian berkecambah dengan membentuk tabung kecambah sehingga jamur dapat masuk ke tubuh inang dan menyebar ke hemocoel. Selanjutnya cendawan menginfeksi saluran makanan dan sistem pernafasan sehingga serangga mati (Hasyim et al., 2005).

Hasil penelitian Surtikanti \& Yasin (2009) menyatakan bahwa media kompos, tanah, dedak maupun campurannya dapat digunakan sebagai media bagi pertumbuhan cendawan B. bassiana. Pengendalian $O$. rhinoceros sasarannya adalah tempat breeding site hama tersebut. Media yang disukai oleh $O$. rhinoceros untuk meletakkan telur dan tempat larva hidup pada bahan organik yang telah melapuk yaitu kotoran sapi, serbuk gergaji, sekam padi dan batang kelapa (Darwis, 1989).
Penelitian tentang kerapatan konidia aplikasi $B$. bassiana pada $O$. rhinoceros langsung telah dilakukan. Hasil Penelitian Sihombing et al., (2014) menunjukkan bahwa persentase mortalitas larva $O$. rhinoceros pada pengamatan 18 HSA yang tertinggi $(100 \%)$ terdapat pada kerapatan konidia B. bassiana 75 g. $^{-1}$ dan terendah $(72,93 \%)$ pada perlakuan $B$.

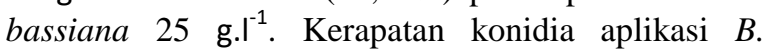
bassiana pada kompos TKKS belum diteliti, oleh karenanya sangat diperlukan untuk memanfaatkannya sebagai biopestisida pada kompos.

Penelitian ini bertujuan untuk mendapatkan kerapatan konidia terbaik $B$. bassiana pada kompos TKKS + serbuk gergaji dalam mengendalikan larva $O$. rhinoceros.

\section{METODE PENELITIAN}

Penelitian ini dilaksanakan pada bulan Februari sampai November 2020 di Kebun Percobaan dan Laboratorium Hama Tumbuhan Fakultas Pertanian Universitas Riau. Penelitian dilakukan secara eksperimen menggunakan Rancangan Acak Lengkap (RAL). Percobaan uji kerapatan konidia cendawan B. bassiana pada media kompos terhadap larva $O$. rhinoceros dengan 6 perlakuan 4 ulangan sebagai berikut: 0 g. $1^{-1}, 15$ g. $1^{-1}, 30$ g. $l^{-1}, 45$ g. $1^{-1}, 60$ g. $1^{-1}$ dan 75 g. $1^{-1}$. Adapun parameter yang diamati adalah jumlah konidia, waktu awal kematian, Lethal Time $\left(\mathrm{LT}_{50}\right)$, persentase mortalitas harian, persentase mortalitas total dan Lethal concentration $\left(\mathrm{LC}_{50,95}\right)$. Data persentase mortalitas harian dianalisis secara deskriptif dan ditampilkan dalam bentuk grafik, sedangkan data lainnya dianalisis dengan menggunakan ANOVA kemudian dilanjutkan dengan uji jarak duncan dengan model linear RAL, untuk menentukan $\mathrm{LC}_{50,95}$ kerapatan konidia $B$. bassiana yang tepat, maka data dianalisis probit menggunakan program POLO-PC (LeOra software, 1987).

\section{Persiapan percobaan}

Isolat Beauveria bassiana yang digunakan berasal dari lahan persawahan di Kabupaten Siak, Riau (Hapsoh et al., 2019). Cendawan B. bassiana diremajakan kembali pada media PDA dalam cawan petri steril dan ditumbuhkan pada suhu ruang $\pm 27^{\circ} \mathrm{C}$. Setelah 7 hari, isolat tersebut digunakan sebagai sumber inokulum untuk pembiakan cendawan pada media beras. TKKS diambil yang telah diinkubasi \pm 1 bulan. TKKS dicacah dengan mesin pencacah untuk mempercepat proses dekomposisi. Serbuk gergaji sebagai media campuran kompos disiapkan. Larva $O$. rhinoceros yang digunakan adalah larva instar 2 yang dibutuhkan dalam penelitian ini sebanyak 10 larva pada masingmasing ember perlakuan.

\section{Perbanyakan Beauveria bassiana}

Beauveria bassiana ditumbuhkan pada media beras dengan cara beras dicuci bersih, lalu beras 
dituangkan ke dalam air mendidih dan diamkan dalam keadaan terendam dan kemudian disaring dan dikering anginkan. Beras tersebut sebanyak \pm 50 gram dimasukkan ke dalam kantong plastik HDPE (High Density Polyethylene) yang tahan panas, ditutup dengan cincin plat lalu ditutup dengan kapas dan aluminium foil. Selanjutnya, media beras disterilkan menggunakan autoclaf selama 35 menit pada suhu $121^{\circ} \mathrm{C}$. Setelah dingin, isolat cendawan $B$. bassiana diinokulasikan pada media beras di dalam laminar flow dengan cara biakan murni $B$. bassiana pada media PDA dipotong-potong (ukuran 1 x $1 \mathrm{~cm}$ per potong), potongan tersebut dimasukkan ke dalam kantong plastik. Cendawan B. bassiana yang tumbuh pada media beras, diambil sesuai perlakuan yaitu $0 \mathrm{~g}$, $15 \mathrm{~g}, 30 \mathrm{~g}, 45 \mathrm{~g}, 60 \mathrm{~g}$, dan $75 \mathrm{~g}$ lalu ditumbuk di dalam mortar. Cendawan $B$. bassiana tersebut dicampurkan dengan 1 liter aquades di dalam erlenmeyer berukuran $1000 \mathrm{ml}$. Suspensi dikocok dengan menggunakan rotary shaker selama 24 jam untuk mempercepat pembelahan sel dan ditambahkan gula pasir sebanyak $0,5 \mathrm{~g}$ tiap $1 \mathrm{~g}$ B. bassiana.

\section{Pembuatan kompos}

Tandan kosong kelapa sawit yang sudah dicacah dan serbuk gergaji dicampur pupuk kandang dengan perbandingan $3: 1$. Media tersebut disiram dengan dekomposer $100 \mathrm{ml}$ (EM4) dan gula merah ditambah dolomit, agar semua bahan tambahan bisa merata keseluruh permukaan kompos perlu dilakukan pembalikan. Kompos ditumpuk dan ditutup dengan menggunakan terpal yang tebal. Pembalikan dilakukan 1 kali seminggu selama 3 bulan.

Kompos yang telah jadi, disterilkan dengan metode tyndalisasi. Tyndalisasi dilakukan dengan cara kompos dimasukkan ke dalam plastik dan ditutup rapat, lalu dikukus menggunakan dandang. Kompos dikukus selama 30 menit bersuhu $100^{\circ} \mathrm{C}$, . Kompos yang steril dikeluarkan dan setelah 24 jam kompos tersebut disterilkan lagi dengan cara yang sama sampai 3 kali ulangan.

\section{Perhitungan Konidia Beauveria bassiana}

Suspensi $B$. bassiana diambil $10 \quad \mathrm{ml}$ dipindahkan ke dalam tabung reaksi yang berisi akuades $9 \mathrm{ml}$, kemudian dirotary mixer selama 1 menit. Demikian seterusnya dengan tahapan yang sama untuk mendapatkan tingkat pengenceran $10^{-2}$, $10^{-3}, 10^{-4}, 10^{-5}$, dan $10^{-6}$. Kerapatan konidia tingkat pengenceran $10^{-6}$ dihitung menggunakan haemocytometer di bawah mikroskop cahaya. Kerapatan konidia per $\mathrm{ml}$ dihitung dengan rumus sebagai berikut (Nuryanti et al., 2012):

$$
J=\frac{t x d}{0,25 x n} \times 10^{6} \text { konidia } / \mathrm{ml}
$$

Keterangan:

$$
\begin{aligned}
\mathrm{J}= & \text { jumlah konidia dalam satu gram media } \\
\mathrm{t}= & \text { jumlah konidia dalam semua kotak bujur } \\
& \text { sangkar yang dihitung }
\end{aligned}
$$

$\mathrm{d}=$ faktor pengenceran bila harus diencerkan $(\mathrm{d}=1$ berarti tidak diencerkan; $\mathrm{d}=10$ berarti diencerkan $1: 10$ )

$0,25=$ konstanta

$\mathrm{N}=$ jumlah kotak bujur sangkar yang dihitung

\section{Aplikasi Beauveria bassiana}

Kompos TKKS + serbuk gergaji dimasukkan ke ember sampai kedalaman $20 \mathrm{~cm}$. Suspensi $B$. bassiana disiram rata ke kompos dengan volume 500 $\mathrm{ml}$ (Fauzana et al., 2019) dan didiamkan selama seminggu.

\section{Infestasi Larva Oryctes rhinoceros}

Kompos yang sudah diinokulasi B. bassiana, masing-masing ember perlakuan diletakkan 10 ekor larva instar 2 pada kedalaman $10 \mathrm{~cm}$ dari permukaan atas kompos, kemudian ditutup dengan kain hitam. Pengamatan mortalitas larva dilakukan selama 14 hari dengan pengamatan periode $12 \mathrm{jam}$.

Pengamatan waktu awal kematian dilakukan dengan menghitung waktu yang dibutuhkan untuk mematikan larva instar 2 O. rhinoceros paling awal. Pengamatan dilakukan 12 jam setelah aplikasi dan dilanjutkan setiap 12 jam berikutnya. Pengamatan Lethal time 50 dilakukan dengan menghitung waktu yang dibutuhkan setiap perlakuan untuk mematikan $50 \%$ larva $O$. rhinoceros. Pengamatan dilakukan setiap 12 jam setelah diberikan perlakuan sampai ada $50 \%$ larva $O$. rhinoceros yang mati dari setiap unit percobaan. Pengamatan terhadap persentase mortalitas harian larva $B$. bassiana dilakukan 12 jam. Menurut Natawigena (1993) persentase mortalitas harian dapat dihitung dengan menggunakan rumus sebagai berikut:

$$
\mathrm{MH}=\frac{\mathrm{a}-\mathrm{b}}{\mathrm{a}} \times 100 \%
$$

Keterangan:

$$
\begin{aligned}
\mathrm{MH}= & \begin{array}{l}
\text { Persentase mortalitas harian larva } O . \\
\text { rhinoceros }
\end{array} \\
\mathrm{a}= & \begin{array}{l}
\text { Jumlah larva } O \text {. } \\
\text { diperlakukan }
\end{array} \\
\mathrm{b}= & \begin{array}{l}
\text { Jumlah larva } O \text {. rhinoceros yang hidup } \\
\text { yang }
\end{array}
\end{aligned}
$$

Pengamatan mortalitas total dilakukan dengan menghitung persentase total larva $O$. rhinoceros yang mati pada tiap kerapatan konidia perlakuan. Menurut Natawigena (1993) persentase mortalitas total dapat dihitung dengan menggunakan rumus sebagai berikut:

$$
\mathrm{MT}=\frac{\mathrm{a}}{\mathrm{b}} \times 100 \%
$$

Keterangan:

MT $=$ Persentase mortalitas total larva $O$. rhinoceros

a = Jumlah larva $O$. rhinoceros yang mati

$\mathrm{b}=$ Jumlah larva $O$. rhinoceros yang diperlakukan 


\section{HASIL DAN PEMBAHASAN}

\section{Waktu awal kematian larva (jam)}

Hasil penelitian menunjukkan bahwa bahwa perlakuan kerapatan konidia $B$. bassiana pada media kompos memberikan pengaruh nyata terhadap waktu awal kematian larva $O$. rhinoceros. Pada perlakuan tanpa cendawan $B$. bassiana 0 g..$^{-1}$ air (kontrol) tidak ditemukan larva $O$. rhinoceros yang mati sampai akhir pengamatan yaitu 336 jam. Hal ini disebabkan tidak adanya konidia cendawan $B$. bassiana sehingga tidak mengakibatkan kematian pada larva sampai akhir pengamatan. Cendawan B. bassiana perlakuan 75 g. $1^{-1}$ air memiliki kerapatan konidia tertinggi yaitu $83,2 \times 10^{8}$ dibandingkan dengan perlakuan lainnya. Perlakuan kerapatan B. bassiana 75 g..$^{-1}$ air berbeda tidak nyata dengan kerapatan $B$. bassiana $60 \mathrm{~g} .1^{-1}$ air dan 45 g. $1^{-1}$ air, namun berbeda nyata dengan kerapatan B. bassiana 30 g. $\mathrm{l}^{-1}$ air dan 15 g. $1^{-1}$ air (Tabel 1).

Tabel 1. Waktu awal kematian larva $O$. rhinoceros pada kompos yang mengandung beberapa kerapatan konidia B. bassiana.

\begin{tabular}{lc}
\hline \multicolumn{1}{c}{ Kerapatan konidia bassiana pada kompos } & $\begin{array}{c}\text { Waktu awal kematian (jam) } \\
(\mathrm{b} \pm \mathrm{SE})\end{array}$ \\
\hline $0 \mathrm{~g} \cdot \mathrm{l}^{-1}$ air $(\mathrm{Kontrol})$ & $336 \pm 0 \mathrm{a}$ \\
$15 \mathrm{~g} \cdot \mathrm{l}^{-1}$ air $\left(25,6 \times 10^{8} \mathrm{kon} / \mathrm{ml}\right)$ & $141 \pm 37,1 \mathrm{~b}$ \\
$30 \mathrm{~g} \cdot \mathrm{l}^{-1}$ air $\left(32 \times 10^{8} \mathrm{kon} / \mathrm{ml}\right)$ & $123 \pm 26,6 \mathrm{~b}$ \\
$45 \mathrm{~g} . \mathrm{l}^{-1}$ air $\left(57,6 \times 10^{8} \mathrm{kon} / \mathrm{ml}\right)$ & $87 \pm 26,6 \mathrm{c}$ \\
$60 \mathrm{~g} \cdot \mathrm{l}^{-1}$ air $\left(64 \times 10^{8} \mathrm{kon} / \mathrm{ml}\right)$ & $69 \pm 20,4 \mathrm{c}$ \\
$75 \mathrm{~g} . \mathrm{l}^{-1}$ air $\left(83,2 \times 10^{8} \mathrm{kon} / \mathrm{ml}\right)$ & $54 \pm 15,4 \mathrm{c}$ \\
\hline
\end{tabular}

Angka-angka pada lajur yang diikuti oleh huruf kecil yang tidak sama berbeda nyata menurut uji DNMRT pada taraf 5\%

Mimba memiliki senyawa aktif azadirakhtin yang Waktu awal kematian tidak berbeda nyata untuk mematikan larva $O$. rhinoceros pada kerapatan konidia cendawan $B$. bassiana $45 \mathrm{~g} . \mathrm{l}^{-1}$ air, $60 \mathrm{~g} . \mathrm{l}^{-1}$ air dan 75 g. $1^{-1}$ air. Hal ini karena tingkat virulensi dan daya kecambah $B$. bassiana sama pada masingmasing kerapatan. Neves \& Alves (2004) menyatakan bahwa waktu kematian serangga dipengaruhi oleh virulensi kerapatan cendawan entomopatogen. Menurut (Feng et al., 1994) kemampuan membunuh isolat Beauveria spp. sangat tergantung pada kerapatan konidia, daya kecambah dan tingkat virulensi. Faktor lain yang turut berperan terhadap tinggi rendahnya virulensi suatu isolat adalah adanya metabolik sekunder yang dihasilkan. Metabolik sekunder yang dihasilkan oleh Beauveria spp. adalah enzim chitinase, protease, lipase, dan esterase (Gupta et al., 1992).

\section{Lethal time $50\left(\mathbf{L T}_{50}\right)$ (jam)}

Hasil sidik ragam menunjukkan bahwa perlakuan beberapa kerapatan konidia $B$. bassiana pada media kompos memberikan pengaruh nyata terhadap lethal time 50 larva $O$. rhinoceros. Hasil uji DNMRT pada taraf $5 \%$ dapat dilihat pada Tabel 2.

Tabel 2. Lethal time 50 larva $O$. rhinoceros setelah infestasi ke kompos yang mengandung beberapa kerapatan konidia B. bassiana.

\begin{tabular}{ll}
\hline \multicolumn{1}{c}{ Kerapatan konidia bassiana pada kompos } & $\left(\mathrm{LT}_{50}(95 \% \mathrm{Cl}) \mathrm{Jam}\right)$ \\
\hline $0 \mathrm{~g} . \mathrm{l}^{-1}$ air $(\mathrm{Kontrol})$ & $14,00(-) \mathrm{a}$ \\
$15 \mathrm{~g} . \mathrm{l}^{-1}$ air $\left(25,6 \times 10^{8} \mathrm{kon} / \mathrm{ml}\right)$ & $14,00(-) \mathrm{a}$ \\
$30 \mathrm{~g} . \mathrm{l}^{-1}$ air $\left(32 \times 10^{8} \mathrm{kon} / \mathrm{ml}\right)$ & $14,00(-) \mathrm{a}$ \\
$45 \mathrm{~g} . \mathrm{l}^{-1}$ air $\left(57,6 \times 10^{8} \mathrm{kon} / \mathrm{ml}\right)$ & $13,75(12,96-14,54) \mathrm{a}$ \\
$60 \mathrm{~g} . \mathrm{l}^{-1}$ air $\left(64 \times 10^{8} \mathrm{kon} / \mathrm{ml}\right)$ & $12,25(9,62-14,88) \mathrm{b}$ \\
$75 \mathrm{~g} . \mathrm{l}^{-1}$ air $\left(83,2 \times 10^{8} \mathrm{kon} / \mathrm{ml}\right)$ & $9,00(7,64-10,36) \mathrm{c}$ \\
\hline
\end{tabular}

Angka-angka pada lajur yang diikuti oleh huruf kecil yang tidak sama berbeda nyata menurut uji DNMRT pada taraf $5 \%$

CI: confidence interval.

Pada perlakuan kerapatan konidia B. bassiana $0 \mathrm{~g} . \mathrm{l}^{-1}$ terlihat tidak ada larva $O$. rhinoceros yang mati sampai akhir pengamatan yaitu 336 jam, hal ini disebabkan karena tidak ada konidia cendawan $B$. bassiana. Waktu yang dibutuhkan untuk mematikan larva $O$. rhinoceros sebanyak $50 \%$ tercepat pada kerapatan konidia cendawan $75 \mathrm{~g} . \mathrm{l}^{-1}$ air yaitu $213 \mathrm{jam}$ setelah aplikasi. Kerapatan konidia B. bassiana 75 g.l ${ }^{-}$ ${ }^{1}$ air berbeda nyata dengan semua perlakuan. 
Hal ini disebabkan kerapatan cendawan $B$. bassiana 75 g. $^{-1}$ memiliki jumlah konidia tertinggi dari perlakuan yang lainnya. Hal ini menunjukkan kerapatan $B$. bassiana yang tinggi dan jumlah konidia yang tinggi maka toksin yang dihasilkan cendawan tinggi sehingga lebih cepat mematikan larva $O$. rhinoceros sebanyak 50\% (Tabel 2). Sudharto et al., (1998) menyatakan bahwa kerapatan konidia yang lebih tinggi mempengaruhi kemampuan cendawan dalam menginfeksi serangga uji.

Cendawan $B$. bassiana dengan kerapatan konidia 15 g. $1^{-1}$ air dan 30 g. $1^{-1}$ air untuk mematikan larva $O$. rhinoceros $50 \%$ membutuhkan waktu paling lama yaitu 336 jam dan tidak berbeda nyata dengan 45 g. $1^{-1}$ air yaitu 330 jam. Hal ini karena cendawan $B$. bassiana masih melakukan penyesuaian pada tubuh larva untuk melakukan penetrasi, sehingga waktu yang dibutuhkan untuk mematikan larva $O$. rhinoceros $50 \%$ belum maksimal.

\section{Mortalitas harian larva (\%)}

Hasil pengamatan persentase mortalitas harian beberapa kerapatan konidia $B$. bassiana pada kompos terhadap larva $O$. rhinoceros menunjukkan kecendrungan peningkatan mortalitas harian larva $O$. rhinoceros dari hari pertama hingga 14 hari setelah aplikasi. Peningkatan mortalitas harian larva $O$. rhinoceros setelah aplikasi beberapa kerapatan konidia cendawan $B$. bassiana dapat dilihat pada Gambar 1.

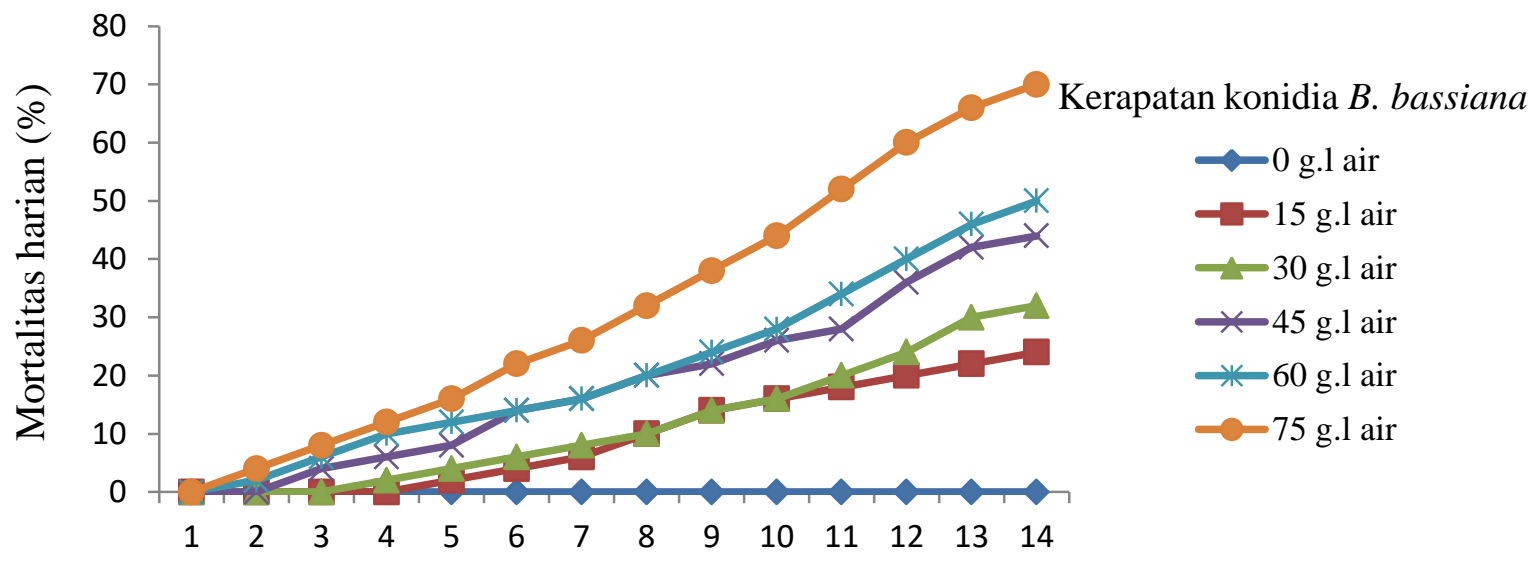

Hari setelah aplikasi

Gambar 1. Mortalitas harian larva O. rhinoceros setelah infestasi ke kompos yang mengandung beberapa kerapatan konidia $B$. bassiana

Mortalitas harian larva $O$. rhinoceros pada perlakuan kerapatan konidia B. bassiana 75 g. $\mathrm{l}^{-1}$ air dan $60 \mathrm{~g} . \mathrm{l}^{-1}$ air terjadi pada hari kedua, terlihat bahwa perlakuan kerapatan konidia $B$. bassiana 75 g. $1^{-1}$ air menunjukkan persentase larva $O$. rhinoceros sebesar $4 \%$ dan 60 g. $1^{-1}$ air sebesar 2\%. Mortalitas harian larva $O$. rhinoceros pada perlakuan kerapatan $B$. bassiana $45 \mathrm{~g} . \mathrm{l}^{-1}$ air terjadi pada hari ketiga sebesar 4\%. Mortalitas harian larva $O$. rhinoceros pada perlakuan kerapatan B. bassiana $30 \mathrm{~g} . \mathrm{l}^{-1}$ terjadi pada hari keempat sebesar $2 \%$. Mortalitas harian larva O. rhinoceros pada perlakuan kerapatan B. bassiana 15 g. $1^{-1}$ air terjadi pada hari kelima sebesar 2\% (Gambar $1)$.

Puncak mortalitas harian larva $O$. rhinoceros pada kerapatan konidia cendawan B. bassiana $75 \mathrm{~g} . \mathrm{l}^{-1}$ air dan 45 g..$^{-1}$ air memiliki mortalitas harian paling tinggi sebesar $8 \%$ pada hari ke 12 , namun lebih dahulu mencapai puncak pada kerapatan konidia $B$. bassiana 75 g..$^{-1}$ air dimulai pada hari ke-11 sedangkan kerapatan konidia B. bassiana 45 g..$^{-1}$ air terjadi pada hari ke-12. Hal ini menunjukkan cendawan $B$. bassiana dengan kerapatan konidia yang rendah mampu menginfeksi dan berkembang dengan cepat pada larva $O$. rhinoceros, sehingga menyebabkan puncak mortalitas yang sama dengan kerapatan konidia $B$. bassiana yang lebih tinggi yaitu 75 g.l air. Hal ini disebabkan perkembangbiakan cendawan didukung oleh banyak faktor. Menurut Prayogo (2006) menyatakan bahwa faktor yang mempengaruhi keefektifan cendawan entomopatogen yaitu kerapatan konidia, kualitas media tumbuh, jenis hama, waktu aplikasi, frekuensi aplikasi dan faktor lingkungan seperti suhu, sinar ultra violet, curah hujan dan kelembaban.

\section{Mortalitas total larva (\%)}

Hasil sidik ragam menunjukkan bahwa kompos yang mengandung beberapa kerapatan konidia cendawan $B$. bassiana dapat memberikan pengaruh yang nyata terhadap mortalitas larva $O$. rhinoceros. Hasil rata-rata mortalitas total larva $O$. rhinoceros setelah dilakukan uji DNMRT pada taraf 5\% dapat dilihat pada Tabel 3 . 
Tabel 3. Mortalitas total larva $O$. rhinoceros setelah infestasi ke kompos yang mengandung beberapa kerapatan konidia B. bassiana hari ke 14 setelah aplikasi

\begin{tabular}{lc}
\hline \multicolumn{1}{c}{ Kerapatan konidia $B$. bassiana pada Kompos } & Mortalitas Total $(\%)(\mathrm{b} \pm \mathrm{SE})$ \\
\hline $0 \mathrm{~g} . \mathrm{l}^{-1}$ air $($ Kontrol) & $0 \pm 0 \mathrm{e}$ \\
$15 \mathrm{~g} . \mathrm{l}^{-1}$ air $\left(25,6 \times 10^{8} \mathrm{kon} / \mathrm{ml}\right)$ & $30 \pm 8,16 \mathrm{~d}$ \\
$30 \mathrm{~g} . \mathrm{l}^{-1}$ air $\left(32 \times 10^{8} \mathrm{kon} / \mathrm{ml}\right)$ & $40 \pm 8,16 \mathrm{dc}$ \\
$45 \mathrm{~g} . \mathrm{l}^{-1}$ air $\left(57,6 \times 10^{8} \mathrm{kon} / \mathrm{ml}\right)$ & $55 \pm 17,32 \mathrm{bc}$ \\
$60 \mathrm{~g} \cdot \mathrm{l}^{-1}$ air $\left(64 \times 10^{8} \mathrm{kon} / \mathrm{ml}\right)$ & $65 \pm 12,90 \mathrm{~b}$ \\
$75 \mathrm{~g} .{ }^{1-1}$ air $\left(83,2 \times 10^{8} \mathrm{kon} / \mathrm{ml}\right)$ & $87 \pm 9,57 \mathrm{a}$ \\
\hline
\end{tabular}

Angka-angka pada lajur yang diikuti oleh huruf kecil yang tidak sama berbeda nyata menurut uji DNMRT pada taraf 5\%, setelah ditransformasi dengan $\operatorname{Arc} \operatorname{Sin} \sqrt{y}$.

b: slope of the probit line, SE: standard eror

Mortalitas total tertinggi terdapat pada perlakuan kerapatan konidia Beauveria bassiana 75 g. $1^{-1}$ air $(87 \%)$ dan terendah yaitu $30 \%$ pada kerapatan konidia $B$. bassiana 15 g. l $^{-1}$ air. Mortalitas serangga uji pada kerapatan konidia B. bassiana 75 g. . $^{-1}$ air $(87 \%)$ berbeda nyata dengan perlakuan lainnya. Kerapatan konidia B. bassiana 60 g. $1^{-1}$ air $(65 \%)$ tidak berbeda nyata dengan 45 g..$^{-1}$ air $(55 \%)$ dan berbeda nyata dengan $15 \mathrm{~g} . \mathrm{l}^{-1}$ air $(30 \%)$. Kerapatan konidia $B$. bassiana 30 g..$^{-1}$ air $(40 \%)$ tidak berbeda nyata dengan $15 \mathrm{~g} . \mathrm{l}^{-1}$ air $(30 \%)$ dan 45 g. $\mathrm{l}^{-1}$ air $(55 \%)$ (Tabel 3). Kerapatan konidia B. bassiana 75 g. $1^{-1}(83,2$ $\mathrm{x} 10^{8} \mathrm{kon} / \mathrm{ml}$ ) air adalah terbaik dibanding perlakuan lainnya karena memiliki mortalitas total tertinggi. Hal ini seiring dengan waktu awal kematian larva $O$. rhinoceros tercepat 54 jam dan lethal time 50 larva $O$. rhinoceros yaitu 9,00 (7,64 - 10,36) (Tabel 2) jam. Semakin tinggi jumlah konidia maka semakin banyak konidia yang menempel dan setelah berkecambah akan berpenetrasi ke dalam tubuh larva, serta semakin banyak toksin beauvericin yang dihasilkan sehingga menyebabkan kematian yang tinggi pada larva. Trizelia (2005) menyatakan bahwa toksin beauvericin menyebabkan terjadinya kenaikan $\mathrm{pH}$ darah, penggumpalan darah dan terhentinya peredaran darah sehingga terjadi kerusakan jaringan pada serangga.Menurut Inglis et al., (1993) bahwa kemampuan patogen untuk bisa menimbulkan infeksi pada serangga ditentukan oleh tiga faktor yaitu patogen, inang dan lingkungan. Dari segi patogen, dosis dan cara aplikasi akan mempengaruhi mortalitas serangga, sedangkan dari segi inang, berbagai faktor fisiologi dan morfologi inang mempengaruhi kerentanan serangga terhadap jamur entomopatogen.

Perlakuan kerapatan konidia B. bassiana 75 g. $1^{-1}$ air pada kompos dapat dikategorikan sebagai bioinsektisida dalam mematikan hama $O$. rhinoceros karena tingkat mortalitasnya cukup tinggi sebesar 87\%. Hal ini sesuai dengan pendapat Steinaus (1963) cit. Hasyim (2007) jamur yang dapat dikategorikan sebagai bioinsektisida adalah cendawan yang berhasil mengendalikan serangga dengan mortalitas sebesar $72 \%$ - 95\%. Cendawan B. bassiana masuk ke dalam tubuh larva $O$. rhinoceros secara kontak yaitu melalui kutikula dengan bantuan enzim kitinase yang mampu menghancurkan kutikula larva $O$. rhinoceros. Salbiah \& Rumi'an (2014) menyatakan bahwa mekanisme infeksi cendawan $B$. bassiana dimulai dari menempelnya propagul cendawan pada kutikula serangga. Wahyudi (2008) menyatakan bahwa secara kimiawi $B$. bassiana mengeluarkan enzim kitinase yang mampu menghancurkan kutikula serangga, sehingga secara mekanis miselium mampu menembus kutikula kemudian masuk ke dalam hemocoel dan berkembang di dalam tubuh serangga. Miselium $B$. bassiana mengeluarkan toksin beuvericin, dan mengkonsumsi bagian internal dari tubuh larva $O$. rhinoceros sehingga nutrisi di dalam tubuh larva habis untuk pertumbuhan cendawan yang mengakibatkan menurunnya aktivitas larva dan mengalami kematian.

\section{Lethal Concentration $\left(\mathrm{LC}_{\mathbf{5 0}, 95}\right)$}

Kerapatan konidia yang tepat untuk mematikan $50 \%$ larva O. rhinoceros adalah $3,3 \%$ atau setara 33 g. $1^{-1}$ air. Kerapatan konidia yang mampu untuk mematikan $95 \%$ larva O. rhinoceros adalah $20,9 \%$ atau setara dengan 209 g. l $^{-1}$ air pada hari ke-14 setelah perlakuan (Tabel 4). Hasil penelitian ini menunjukkan dengan kerapatan konidia cendawan $B$. bassiana lebih dari 30 g. $1^{-1}$ air sudah dapat membunuh larva $O$. rhinoceros sebesar $50 \%$.

Tabel 4. Lethal concentration 50 dan $95\left(\mathrm{LC}_{50}\right.$ dan $\left.\mathrm{LC}_{95}\right)$

\begin{tabular}{ccc}
\hline Hari Pengamatan & $\mathrm{LC}_{50}(95 \% \mathrm{Cl})$ & $\mathrm{LC}_{95}(95 \% \mathrm{Cl})$ \\
\hline 2 & $14,7(-)$ & $29,8(-)$ \\
6 & $20,4(10,7-435,6)$ & $237,2(10,7-71256,9)$ \\
10 & $8,6(5,9-26,1)$ & $143,4(38,9-1901,0)$ \\
14 & $3,3,(1,9-4,9)$ & $20,9(10,5-207,5)$ \\
\hline
\end{tabular}

CI: confidence interval. 
Hasil penelitian Soetopo \& Indrayani (2007) menunjukkan $\mathrm{LC}_{50}$ dan $\mathrm{LC}_{90}$ Isolat cendawan $B$. bassiana (Bb4a) pada 16 hari setelah perlakuan lebih rendah $\left(5,22 \times 10^{6}\right.$ dan $6,10 \times 10^{9}$ konidia/ml $)$ dibanding $\mathrm{LC}_{50}$ dan $\mathrm{LC}_{90}$ isolat $B$. bassiana $\mathrm{BbEd} 10\left(3,93 \times 10^{7}\right.$ konidia/ml). Selain itu hasil penelitian Permadi et al., (2017) menunjukkan hasil terbaik $\mathrm{LC}_{50}$ yang diperoleh dari pengujian $B$. bassiana terhadap imago D. citri sebesar $1,52 \times 10^{8} \mathrm{konidia} / \mathrm{ml}$.

\section{Perubahan perilaku dan morfologi larva $O$. rhinoceros}

Larva $O$. rhinoceros mengalami perubahan tingkah laku 1 hari setelah aplikasi dengan pergerakan yang lambat dan abnormal. Menurut Prayogo et al. (2005) serangga yang terinfeksi jamur entomopatogen umumnya menunjukkan gejala penurunan selera makan, aktivitas pergerakan menjadi lambat, lemas, perilaku abnormal, dan diakhiri dengan kematian.

Hasil pengamatan menunjukkan perubahan morfologi larva terjadi pada 1 hari setelah aplikasi sampai cendawan $B$. bassiana mati tertutup miselium B. bassiana. Terjadi perubahan morfologi larva dari perubahan tekstur tubuh dan warna tubuh. Perubahan tekstur tubuh larva $O$. rhinoceros setelah aplikasi menjadi lunak dan berkerut, hal ini disebabkan toksin B. bassiana mengkonsumsi bagian internal tubuh larva sehingga nutrisi di dalam tubuh larva habis untuk pertumbuhan $B$. bassiana yang mengakibatkan kematian.

Perubahan morfologi larva juga terjadi pada warna kulit larva setelah aplikasi $B$. bassiana yaitu larva mati dengan warna kulit kuning kemerahan, kemudian menghitam, kemudian tubuh kaku lalu mulai keluar miselium berwarna putih pada sela kutikula dan perlahan miselium cendawan menutupi seluruh tubuh larva $O$. rhinoceros. Perubahan morfologi terjadi selama 10 hari sampai miselium muncul di kutikula larva. Miselium awalnya muncul antara segmen kepala dengan toraks. Selanjutnya pada bagian ekor dan tungkai, setelah itu seluruh tubuh larva tertutupi oleh miselium berwarna putih. Hal ini sesuai dengan pernyataan Clarkson \& Chamley (1996) bahwa miselium pertama sekali keluar dari tubuh serangga pada bagian antara segmen antena, antara segmen kepala dan toraks, antara segmen toraks dengan abdomen, bagian ekor dan seluruh permukaan tubuh serangga ditutupi miselium cendawan entomopatogen. Perubahan morfologi larva O. rhinoceros dapat dilihat pada Gambar 2.

Boucias \& Pendland (1998) menyatakan perubahan warna hitam yang terjadi pada tubuh serangga disebabkan oleh proses melanisasi yang merupakan suatu bentuk pertahanan tubuh serangga melawan patogen. Miselium awalnya muncul antara segmen kepala dengan torak, selanjutnya pada bagian ekor dan tungkai. Setelah itu permukaan tubuh larva yang terinfeksi ditutupi oleh miselium yang berwarna putih. Rosmini \& Nasir (2013) menyatakan bahwa larva yang mati karena terinfeksi oleh $B$. bassiana mengeras dan berwarna coklat kehitam-hitaman yang lama kelamaan berubah manjadi putih. Warna putih ini disebabkan karena seluruh tubuh telah diselimuti oleh miselium dan miselium muncul dipermukaan larva yang mati didukung oleh kelembaban yang tinggi.
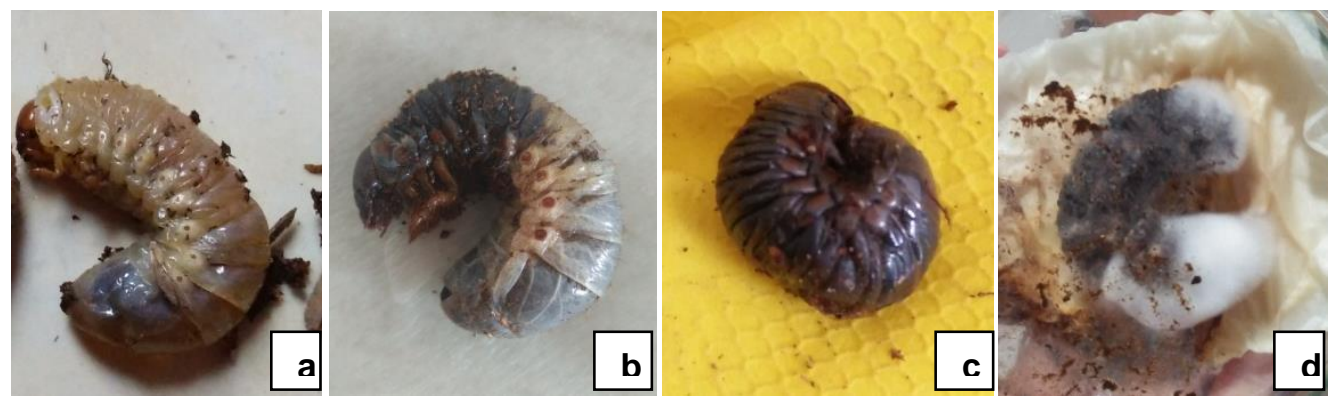

Gambar 2. Pengamatan perubahan morfologi larva O. rhinoceros terinfeksi B. bassiana (a) Larva O. rhinocero yang baru mati, (b) Larva O.rhinoceros yang kaku, (c) Larva O. rhinoceros yang menghitam, (d) Larva O.rhinoceros yang diselimuti miselium berwarna putih.

\section{KESIMPULAN DAN SARAN}

Kompos tandan kosong kelapa sawit + serbuk gergaji yang mengandung konidia cendawan $B$. bassiana 75 g. $1^{-1}\left(83,2 \times 10^{8} \mathrm{kon} / \mathrm{ml}\right)$ mempunyai kemampuan terbaik dalam mengendalikan larva $O$. rhinoceros yang menyebabkan awal kematian 54 jam setelah aplikasi, yaitu 213 jam setelah aplikasi, mortalitas total larva yang dapat dikendalikan sebesar $87 \%$ dan $\mathrm{LC}_{50}$ sebesar $3,3 \%$ atau setara $33 \mathrm{~g} .1^{-1}$ pada 14 hari setelah perlakuan.

\section{UCAPAN TERIMA KASIH}

Terima kasih penulis ucapkan kepada Kementerian riset, teknologi dan Pendidikan tinggi Ristekdikti atas didanainya penelitian ini pada skim hibah Tesis Magister 2020 no Kontrak 454/UN.19.5.1.3/PT.01.03/2020..

\section{DAFTAR PUSTAKA}

Badan Pusat Statistik (BPS) Provinsi Riau. 2017. Riau dalam Angka 2013. BPS, Pekanbaru. 
Bedford GO. 2013. Long-term reduction in damage by rhinoceros beetle Oryctes rhinoceros (L.) (Coleoptera: Scarabaeidae: Dysnastinae) to coconut palm at Oryctes nudivirus release site on viti levu, Fiji. 8(49): 6422-6425.

Boucias DG, \& Pendlan JC. 1998. Priciple of insect pathology. Kluwer Academic Publisher. Boston.

Clarkson JM, \& Chamley AK. 1996. New insight into the mecanisms of fungal pathogenesis insects. Trends in Microbiology. 4(5): $197-$ 203.

Darwis M. 1989. Pengaruh Jenis Media Organik dan Kedalaman Inokulum Metharizium anisopliae terhadap Mortalitas Larva Oryctes rhinoceros. Balai Penelitian Kelapa, Madano.

Daud IT. 2007. Sebaran serangan hama kumbang kelapa Oryctes rhinoceros (Coleoptera: Scarabaeidae) di Kecamatan Mattirobulu Kabupaten Pinrang. Prosiding Seminar Ilmiah dan Pertemuan Tahunan PEI dan PFI XVIII Komda Sul-Sel: 306-318.

Fauzana H, Nelvia, Rustam R, Puspita F, Arda F, \& Kortima E. 2019. Pemanfaatan biopestisida Metharizium anisopliae mengendalikan larva Oryctes rhinoceros pada media tangan kosong kelapa sawit yang dikomposkan (METANKOS). Laporan Penelitian LPPM Universitas Riau. Pekanbaru. (Tidak dipublikasikan).

Feng MG, Poprowski TJ, \& Khachatourisans. 1994. Production, Formulation and Aplication of the Entomopathogenic Fungus Beauveria bassiana for Insect Control. Biocontrol Science and Technology. 4:3-34.

Gupta SC, Leathers TD, Sated \& Ignoffo CM. 1992. Insect cuticle-degrading enzymes from the entomogenous fungus Beauveria spp. Exp. Mycol. 16:132-137.

Hapsoh, Salbiah D, \& Dini IR. 2019. Ketahanan Tanaman Terhadap Serangan Hama Dengan Aplikasi Agens Hayati Mendukung Pertanian Terpadu Berkelanjutan. Laporan Penelitian. LPPM UNRI.

Hasyim A. 2007. Peningkatan infektivitas jamur entomopatogen Beauveria bassiana (Balsamo) Vuill. Pada berbagai bahan carrier untuk mengendalikan hama penggerek tongkol pisang Cosmopolites sordidus Germar di lapangan. Jurnal Horti. 17(40): 335-342.

Hasyim A, Yasir H, \& Azwana. 2005. Seleksi substrat untuk perbanyakan Beauveria bassiana (Balsamo) Vuillemin dan infektivitasnya terhadap hama penggerek bonggol pisang, Cosmopolites sordidus Germar. J. Hort. 15(2):116-123.

Inglis GD, Goette MS, \& Johnson DL. 1993. Persistance of the entomopathogenic fungus Beauveria bassiana on phylloplanes of crested wheatgrass and alfalfa. Biological Control. 3: 258-270.

Kiswanto, Purwanto JH, \& Wijayanto B. 2008. Teknologi Budidaya Kelapa Sawit. Badan Penelitian dan Pengembangan Pertanian. Jakarta.

Natawigena H. 1993. Dasar-dasar Perlindungan Tanaman. Triganda Karya, Bandung.

Neves PMOJ \& Alves SB. 2004. External events related to the infection process of Comitermes cumulans (kollar) (Isoptera: Termitidae) by the entomopatogenic fungi Beauveria bassiana and Metarhizium anisopliae. Journal of the Neotrapical Entomol. 33(1): 051-056.

Permadi MA, Anwar R, \& Santoso T. 2017. Pemanfaatan cendawan Beauveria bassiana (Bals.) Vuill. sebagai miko-insektisida terhadap kutu loncat jeruk Diaphorina citri Kuw. (Hemiptera: Liviidae). BioLink. 4(1): 86-88.

Prayogo Y, Wedanimbi T, Marwoto. 2005. Pemanfaatan cendawan entomopatogen Metarhizium anisopliae untuk mengendalikan ulat grayak Spodoptera litura pada kedelai. Jurnal Penelitian dan Pengembangan Pertanian. 94 (1): 19-26.

Prayogo Y. 2006. Upaya mempertahankan keefektifan cendawan entomopatogen untuk mengendalikan hama tanaman pangan. Jurnal Litbang Pertanian, 24(1):19-26.

Pujiastuti Y, Setiawan JG, \& Arinafril. 2010. Pendugaan perkembangan populasi Oryctes rhinoceros L. (Coleoptera: Scarabaeidae) di perkebunan kelapa sawit (Elaeis guineensis Jacq.). JRL. 6(2): $199-205$.

Purnamayani R. 2013. Teknologi Pembuatan Kompos Tandan Kosong Kelapa Sawit. Balai Pengkajian Teknologi Pertanian Jambi. Jambi.

Rahmadi R, Awaluddin A, \& Itanawita. 2014. Pemanfaatan limbah padat tandan kosong kelapa sawit dan tanaman pakis-pakisan untuk produksi kompos menggunakan aktivator EM-4. Jurnal Jomfmipa, 1(2), 245253.

Rosmini \& Nasir B. 2013. Pemanfaatan jamur entomopatogen Beauveria bassiana lokal Sulawesi Tengah untuk pengendalian Spodoptera exigua dan Lyriomisa chinensis hama endemik pada bawang merah di Sulawesi Tengah. J. Agroland. 20 (1) : $37-$ 45.

Salbiah D, \& Rumi’an. 2014. Cendawan Entomopatogen Beauveria bassiana Vuillemin Lokal sebagai Agen Pengendali Hama Walang Sangit (Leptocorisa oratorius Fabricius) pada Tanaman Padi Sawah. Prosiding Seminar Nasional BKS PTN 
Wilayah Barat Bidang Ilmu Pertanian. Universitas Lampung. Lampung.

Sihombing RH, Oemry S, \& Lubis L. 2014. Uji efektifitas beberapa entomopatogen pada larva Oryctes rhinoceros L. (Coleoptera: Scarabaeidae) di laboratorium. Jurnal Online Agroekoteknologi. 2(4) : 1300- 1309.

Soetopo D, \& Indrayani IGAA. 2007. Status teknologi dan prospek Beauveria bassiana untuk pengendalian serangga hama tanaman perkebunan yang ramah lingkungan. J. Perspektif. 6 (1): 29 - 46.

Sudharto PS, Aini ZA, Ginting CU, \& Papierok B. 1998. Perkembangan jamur Cordyceps aff. Miliaris pada media dedak padi dan patogenitasnya terhadap kepompong
Setothosea asigna van Eacke. Jurnal penelitian kelapa sawit. 6(2): 141-151.

Surtikanti, \& Yasin M. 2009. Keefektifan entomopatogenik Beauveria bassiana Vuill. dari berbagai media tumbuh terhadap Spodoptera litura F. (Lepidoptera : Noctuidae) di laboratorium. Prosiding Seminar Nasional Serealia.

Trizelia. 2005. Cendawan Entomopatogen Beauveria bassiana (Bals.) Vuill. (Deuteromycota; Hyphomycetes): Keragaman Genetik, Karakterisasi Fisiologi, dan Virulensinya terhadap Crocidolomia pavonana (F.) (Lepidoptera; Pyralidae). Tesis Sekolah Pasca Sarjana. Institut Pertanian Bogor. Bogor. (Tidak dipublikasikan). 